\title{
High protein for all is it currently a state of art in critical care nutrition?
}

\section{Summary}

Protein is an integral part of critical care nutrition. It is needed to build, maintain and repair body tissue and also utilized for energy in increasing amounts during stress (1gm protein provides $4 \mathrm{KCls}$ ). Critically ill patient can lose up to $1 \mathrm{~kg}$ of LBM daily and loss of LBM is associated with increased mortality. We have suggested earlier that protein intake is not a one size fits all. Using protein intake per kilogram fat-free mass as a reference, we have proposed adjusted body weight for underweight and obese critically ill patients. Protein requirement based on the new ASPEN 2016 should be in a range of $1.2-2 \mathrm{gm} / \mathrm{kg} /$ day which is very difficult to be achieved with current $\mathrm{EN}$ formulae, and it has to be supplemented with extra protein added to EN. Surgical subsets and renal failure patients on renal replacement therapy should receive even a higher protein requirement $(1.2-2.5 \mathrm{gm} / \mathrm{kg} /$ day). Energy and protein must now be seen as a "power couple" in the new nutrition paradigm.
Volume 6 Issue I - 2016

\section{Khaled Sewify}

Editor-in-Chief, Senior Consultant Intensivist, Saudi Arabia

Correspondence: Khaled Sewify, FRCPE, FCCP, EDIC, CS Acute Medicine UK, Senior Consultant Intensivist, Editor-inChief: ww.icugate.com, King Fahd Military Medical Complex, Dhahran- 31932, P.O. Box 946, Saudi Arabia, Tel 966-54480229, Email drsewifie@hotmail.com

Received: October 01, 2016 | Published: November 01, 2016

\section{Introduction}

Proteins and amino acids are widely considered to be subcomponents in nutritional support. However, they are fundamental to recovery and survival, not only for their ability to preserve active tissue (protein) mass but also for a variety of other functions. Although the body adapts in some ways to starvation, metabolic stress in patients causes increased protein turnover and loss of lean body mass.

\section{Basis of protein requirement}

Body protein is in a constant state of protein turnover, with protein synthesis and protein breakdown levels estimated to be in the order of $350 \mathrm{~g} /$ day. Actually, this is 3.5-5 times a normal daily protein intake. A reference man of $70 \mathrm{~kg}$ contains $10 \mathrm{~kg}$ of protein, which is replaced in 28 days.

Herridge et al. ${ }^{1}$ followed 109 survivors of ARDS for up to 5 years after discharge from the ICU. All patients reported poor functional status with proximal weakness and fatigue at discharge. At 1 year, the distance walked in 6 minutes was $66 \%$ of predicted which increased to $76 \%$ of predicted at 5 years.

\section{Drawbacks of protein deficiency in critically illness}

The progressive and rapid loss of body mass and muscle is well known to occur in patients with critical illness was termed hypermetabolism. Septic autocannibalism was a term used to describe the loss of muscle mass that does not benefit from increasing AA provision above minimum requirements. The net result is anabolic resistance which is frequently observed in critically ill patients and refers to the state in which a patient is resistant to the normal stimulatory effect of AAs on muscle protein synthesis.

Three main factors explain anabolic resistance: splanchnic sequestration of AAs following feeding, which decreases the AAs available to muscles; insulin resistance, which limits AA uptake into muscles and hinders the maintenance of muscle protein; and blunted responses to AAs with anabolic properties, such as the essential AA leucine.

\section{Histological changes in skeletal muscles after ICU admission}

Atrophy of skeletal muscle mass is an almost universal problem in survivors of critical illness and is associated with significant shortand long-term morbidity. The loss of muscle mass is associated with muscle weakness, prolonged mechanical ventilatory support, fatigue and delayed recovery. This disorder is known as critical illness myopathy (CIM) or intensive care unit-acquired weakness (ICUAW). CIM is characterized by a diffuse non-necrotizing myopathy accompanied by fiber atrophy, fatty degeneration of muscle fibers and fibrosis. CIM is exceedingly common in ICU survivors, being reported in up to $46 \%$ of cases. Zudin A et al. ${ }^{2}$ proved in his study when evaluated critically ill patients with histopathological analysis in addition to B-Mode ultrasound and biochemical analysis that skeletal muscle necrosis and muscle wasting occurred early and rapidly during the first week of critical illness and was more severe among those with multiorgan failure. Interestingly, the incidence of acute myofiber necrosis affected $40 \%$ of patients in his study.

\section{Persistentinflammation,immunosuppression, catabolism syndrome (PICS)}

It is a new phenotype of multiple organ failure and a new horizon for surgical ICU which is more common in elderly patients $>65$ years. There is a considerable portion of patients that survive acute critical illness and MOF who entered into chronic critical illness (CCI defined as being in the ICU for $>14$ days with ongoing low grade organ dysfunction). Gentile and Moore et al, characterized PICS as: ICU stay $>14$ days, C-reactive protein $>150 \mathrm{Kg} / \mathrm{dL}$, Total lymphocyte count $<0.8$, weight loss $>10 \%$ during hospitalization or body mass index $<18$, creatinine height index $<80 \%$, azlbumin level $<3 \mathrm{gm} / \mathrm{dl}$, pre-albumin level $<10 \mathrm{mg} / \mathrm{dl}$, retinol binding protein $<10 \mathrm{mcg} / \mathrm{dl}$. PICS patients were observed to clinically lose tremendous amounts of lean body mass despite optimal nutrition causing profound weakness, suffer from recurrent nosocomial infections, decubitus ulcers, and have poor wound healing.

The persistent smoldering inflammatory and catabolic state, produces a "cachexia" phenotype for which current ICU interventions are ineffective, rendering PICS extremely difficult to treat. Stopping 
this process, slowing the progression, or even reversing PICS presents many challenges. Currently, there is no existing literature for nutritional support in PICS, but, as defined earlier, one of the main characteristic of these patients is profound malnutrition.

\section{Does loss of LBM is associated with mortality?}

Loss of LBM is devastating and mortality is approaching 100\% in case of loss of $40 \%$ of LBM so whatever done, the outcome is very poor and the patient will be at high risk of death (Table 1).

\begin{tabular}{lll}
\hline \% Loss of LBM & Complications & $\begin{array}{l}\text { \% Associated } \\
\text { mortality }\end{array}$ \\
\hline 10 & $\begin{array}{l}\text { Decreased Immunity Increased } \\
\text { Infections }\end{array}$ & 10 \\
& $\begin{array}{l}\text { Decreased Healing Increased } \\
\text { Weakness and Infections }\end{array}$ & 30 \\
30 & $\begin{array}{l}\text { Too weak to sit Pressure Ulcers, } \\
\text { Pneumonia and No Healing }\end{array}$ & 50 \\
40 & Death usually from Pneumonia & 100 \\
\hline
\end{tabular}

\section{What is the effect of high protein on LBM?}

The realistic aim of nutrition support is to blunt the loss of $L B M$. Protein consumption does three things related to lean mass. First, protein breaks down to amino acids. Amino acids are the building blocks for virtually every tissue in the body, including muscle. In critically ill, because of anabolic resistance, there will be an increase amino acid needs, which is why it's difficult to maintain muscle. Second, protein consumption stimulates protein synthesis. Third, it reduces protein breakdown. When the rate of protein synthesis is greater than protein breakdown, the body produces a net increase in lean body mass. When protein breakdown exceeds synthesis, the body loses lean body mass.

\section{Does increased protein delivery reduce mortality in ICU patients?}

Studies agreed on the importance of adequate protein supply $\geq 1.2 \mathrm{~g}$ $\mathrm{kg} /$ day for outcome. As proved in Alberada et al. ${ }^{3}$ Every Additional 30gm Protein/day is Associated with Reduced Mortality. Also Van Zanten et al. proved in the MetaPlus randomized, double-blind, multicenter trial that Among adult patients on mechanical ventilation in the ICU, High-protein enteral nutrition enriched with immunemodulating nutrients (IMHP) compared with standard high-protein enteral nutrition (HP) did not improve infectious complications or other clinical end points and may be harmful as suggested by increased adjusted mortality at 6 months. So this trial stressed on the importance of high protein rather than anything else. Allngstrup MJ et al. ${ }^{4}$ showed in his Prospective observational cohort study of 113 ICU patients in a tertiary referral hospital that in these severely ill ICU patients, a higher provision of protein and amino acids was associated with a lower mortality. This was not the case for provision of energy or measured resting energy expenditure or energy or nitrogen balances.

\section{When to start high protein supplements, early or late?}

Peter JM Weijs et al. revealed that in mixed medical-surgical critically ill patients with prolonged mechanical ventilation $(>72$ hours), that in non-septic critically ill patients, early high protein intake was associated with lower mortality $37 \%$ for $<0.8 \mathrm{~g} / \mathrm{kg}, 35 \%$ for 0.8 to $1.0 \mathrm{~g} / \mathrm{kg}, 27 \%$ for 1.0 to $1.2 \mathrm{~g} / \mathrm{kg}$, and $19 \%$ for $\geq 1.2 \mathrm{~g} / \mathrm{kg}$ $(P=0.033)$. For these, a protein intake level of $\geq 1.2 \mathrm{~g} / \mathrm{kg} / \mathrm{day}$ was significantly associated with lower mortality (OR $0.42,95 \%$ CI 0.21 to $0.83, P=0.013$ ) and early energy overfeeding with higher mortality. In septic patients early high protein intake had no beneficial effect on mortality. PepUp protocol created by Heyland and has been published in Canadian Critical Care Nutrition Website suggested to start early protein (Penny protein $14 \mathrm{gm}$ in $120 \mathrm{ml}$ sterile water tid in addition to high protein semi elemental feed containing peptide, Peptamen) in all critically ill patients including septic or a septic (except hepatic encephalopathy and renal failure patients). Protein lost in critically ill trauma and sepsis patients were observed to be $2 \mathrm{~kg}$ in 10 days for the $0.9 \mathrm{~g} / \mathrm{kg}$ protein intake level but only half $(8 \%)$ at $1.2 \mathrm{~g} / \mathrm{kg}$. Therefore, early protein requirement should at least be considered.

\section{Does the type of protein matter?}

Despite, it has been not mention in the ASPEN 2016, Whey protein is considered by experts to be an excellent source of protein. It is one of the two proteins found in milk, with the other being Casein Protein and it is the water-soluble part of milk. Whey is used as a protein supplement and very useful for hitting targeted daily protein goals. It is absorbed faster than other forms of protein, which means it also increases muscle protein synthesis used to break a fasted state. ${ }^{5-18}$

Whey-based protein (high in leucine) increases muscle synthesis compared to soya or casein-based protein. Whey protein increased blood levels of essential amino acids and the creation of muscle protein. Arginine enriched enteral formula is recommended in trauma patients especially traumatic brain injury. Glutamine enriched enteral formula, till recently, it has been recommended as a standard of care for high risk surgical, trauma and burn patients but after REDOX trial being negative, the new ASPEN 2016 recommended against its routine use in critically ill patients. Despite the fact that glutamine has been used in these study in a very strange way, e.g. very high dose, both enteral and parenteral and most of the patients was in shock and MOF which is totally Contrary to common practice. Most experts believe that enteral glutamine is still very important for those selective group of patients awaiting new evidence.

\section{Should we reduce protein supplementation in critically III nephrology patients?}

The ASPEN guidelines suggested the use of standard ICU recommendations for protein $(1.2-2 \mathrm{~g} / \mathrm{kg}$ actual body weight per day). If electrolyte imbalances develop, specialty formulation designed for renal failure maybe considered. They recommend the use protein up to a maximum of $2.5 \mathrm{~g} / \mathrm{kg} / \mathrm{d}$ in patients receiving frequent hemodialysis or CRRT.

\section{What about the surgical subsets of critically III patients?}

High protein requirements at range of $1.2-2.5 \mathrm{~g} / \mathrm{kg} / \mathrm{day}$ together with 15-30grams per liter of volume lost in the negative pressure management systems required in patients with open abdomen. The use of immune-modulating enteral formulas containing arginine and fish oil should be considered in the majority of these surgical subsets. The evidence is lacking in burn population.

\section{Does it matter enteral or parenteral protein?}

There is no randomized control trial looked at the supplemental parenteral protein alone on top of inadequate EN versus inadequate 
EN alone. So still the ASPEN 2016 is talking about protein and calories as a one package and the recommendation is to start TPN as soon as possible in patient at high nutrition risk (NRS-2002 $\geq 5$ or NUTRIC score $\geq 6$ ) or severely malnourished, and when EN is not possible. While patients with low nutrition risk who are unable to meet at least $60 \%$ of energy and protein requirements by $\mathrm{EN}$ route alone to consider supplemental PN only after 7-10 days.

\section{What is the current protein intakes in ICU patients?}

According 2013 survey, the average daily protein given to critically ill patient was only $0.8 \mathrm{gm} / \mathrm{kg} / \mathrm{day}$.

\section{Protein supplementations based of the current guidelines}

ESPEN 2009: $1.3-1.5 \mathrm{gm} / \mathrm{kg} /$ day.

Canadian Critical Care Nutrition 2015: No clear recommendations.

ASPEN 2016: $1.2-2 \mathrm{gm} / \mathrm{kg} /$ day.

\section{Acknowledgments}

None.

\section{Conflicts of interest}

The author declares there is no conflict of interest.

\section{Funding}

None.

\section{References}

1. Batt J, dos Santos CC, Herridge MS. Muscle injury during critical illness. JAMA. 2013;310(15):1569-1570.

2. ZA Puthucheary, Jaikitry Rawal, Mark McPhail. Acute skeletal muscle weakness in critical illness. JAMA. 2013;310(15):1591-1600.

3. Alberda $\mathrm{C}$, Gramlich L, Jones $\mathrm{N}$, et al. The relationship between nutritional intake and clinical outcomes in critically ill patients: results of an international multicenter observational study. Intensive Care Med. 2009;35(10):1728-1737.
4. Allingstrup MJ, Esmailzadeh N, Wilkens Knudsen A, et al. Provision of protein and energy in relation to measured requirements in intensive care patients. Clin Nutr. 2012;31(4):462-468.

5. Berg A, Rooyackers O, Bellander BM, et al. Whole body protein kinetics during hypocaloric and normocaloric feeding in critically ill patients. Crit Care. 2013;17(4):R158.

6. Wischmeyer PE. The evolution of nutrition in critical care: how much, how soon? Crit Care. 2013;17(Suppl 1):S7.

7. Strack van Schijndel RJ, Weijs PJ, Koopmans RH, et al. Optimal nutrition during the period of mechanical ventilation decreases mortality in critically ill, long-term acute female patients: a prospective observational cohort study. Crit Care. 2009;13(4):R132.

8. Weijs PJ, Stapel SN, de Groot SD, et al. Optimal protein and energy nutrition decreases mortality in mechanically ventilated, critically ill patients: a prospective observational cohort study. JPEN J Parenter Enteral Nutr. 2012;36(1):60-68.

9. Casaer MP, Wilmer A, Hermans G, et al. Role of disease and macronutrient dose in the randomized controlled EPaNIC trial: a post hoc analysis. Am J Respir Crit Care Med. 2013;187(3):247-255.

10. Vincent JL, Preiser JC. When should we add parenteral to enteral nutrition? Lancet. 2013;381(9864):354-355

11. Heidegger CP, Berger MM, Graf S, et al. Optimisation of energy provision \&\& with supplemental parenteral nutrition in critically ill patients. Lancet. 2013;381(9864):385-393.

12. Volpi E, Campbell WW, Dwyer JT, et al. Is the optimal level of protein intake for older adults greater than the recommended dietary allowance? J Gerontol A Biol Sci Med Sci. 2013;68(6):677-681.

13. Wischmeyer PE. The evolution of nutrition in critical care: how much, how soon? Crit Care. 2013;17(Suppl 1):S7.

14. Dardevet D, Ré mond D, Peyron MA, et al. Muscle wasting and resistance of muscle anabolism: the 'anabolic threshold concept' for adapted nutritional strategies during sarcopenia. Sci World J. 2012:269531.

15. Demling RH. Nutrition, anabolism and wound healing process. Eplasty. 2009;9:e9.

16. Kress JP, Hall JB. ICU-acquired weakness and recovery from critical illness. N Engl J Med. 2014;371(3):1626-1635.

17. Herridge MS, Cheung AM, Tansey CM, et al. One-year outcomes in survivors of the acute respiratory distress syndrome. $N$ Engl J Med. 2003;348(8):683-693. 